\title{
Intra- and Extra- Pelvic Multidisciplinary Surgical Approach of Retroperitoneal Sarcoma: Case Series Report
}

\author{
Heekyoung Song \\ Catholic University of Korea School of Medicine \\ Jung Hwan Ahn \\ Catholic University of Korea School of Medicine \\ Yuyeon Jung \\ Catholic University of Korea School of Medicine \\ Jae Yeon Woo \\ Catholic University of Korea School of Medicine \\ Yang-Guk Chung \\ Catholic University of Korea School of Medicine \\ Keun Ho Lee $(\square$ hohoho@catholic.ac.kr) \\ Catholic University of Korea https://orcid.org/0000-0001-9005-7796
}

\section{Research Article}

Keywords: Retroperitoneal Neoplasms, Sarcoma, Margins of Excision

Posted Date: September 3rd, 2021

DOI: https://doi.org/10.21203/rs.3.rs-845798/v1

License: (1) This work is licensed under a Creative Commons Attribution 4.0 International License. Read Full License 


\section{Abstract}

Objective: We aim to describe our experience of multidisciplinary surgical resection of retroperitoneal sarcoma (RPS), including intra- and extrapelvic approaches.

Method: Multidisciplinary surgery is an anatomical approach combining intra- and extraperitoneal access within the same surgery to achieve complete RPS removal. This retrospective review of the records of patients who underwent multidisciplinary surgery for RPS analyzed surgical and survival outcomes.

Result: Eight patients underwent 10 intra- and extrapelvic surgical resection and their median mass size was $12.75 \mathrm{~cm}$ (range, $6-45.5 \mathrm{~cm}$ ). Using an intrapelvic approach, laparoscopy-assisted surgery was performed in 4 cases and laparotomy surgery in 6 cases. Using an extrapelvic approach, ilioinguinal and posterior approaches were used in 4 cases each, prone position and midline skin incision were shared in 1 case. All patients' RPS masses were removed completely and 4 patients achieved R0 resection through intra- and extrapelvic surgery. Additionally, pelvic lymph node dissections or prophylactic fixation or revision of structures were conducted. The median estimated blood loss was $2000 \mathrm{~mL}$ (range, 300-20 $000 \mathrm{~mL}$ ) and the median hospitalization was 12.6 days (range, 9-69 days). Reoperation was needed in 2 patients (one for wound necrosis, the other for bowel perforation and wound necrosis). The median overall survival rate and median progression-free survival were 64.6 months and 13.7 months, respectively.

Conclusion: RPS are therapeutically challenging based on their locations and high risk of recurrence. Considering that, intra- and extrapelvic surgical approach could improve the macroscopic security of the surgical margin.

\section{Introduction}

Retroperitoneal sarcoma (RPS) is a rare malignancy arising from mesenchymal cells that most commonly presents as an abdominal mass and is associated with a poor prognosis [1]. Liposarcoma, either well differentiated or dedifferentiated (WDLPS or DDLPS), is the most frequent histological subtype (50-63\%), followed by leiomyosarcoma (LMS) (19-23\%) [2,3]. Other less frequent soft tissue sarcoma subtypes in the retroperitoneum include solitary fibrous tumor (SFT), malignant peripheral nerve sheath tumor (MPNST), synovial sarcoma and undifferentiated pleomorphic sarcoma (UPS) [2, 3]. The incidence is approximately 0.5-1 case per 100 000, and these tumors are almost always sporadic [4]. Surgery is the mainstay of curative therapy, and local control is critical for outcome [5]. Also, Korean obstetric gynecology group also noted that absent residual disease is one of important prognostic factors in leiomyosarcoma patients [Hazard ratio 5.07, p< 0.001] [6]. Conversely, the role of chemotherapy in the management of localized RPS is still unproven and the potential benefit of radiotherapy (RT) remains controversial, and it is currently under evaluation [7]. Nevertheless, anatomic constraints in the retroperitoneum limit the ability to achieve wide resection margin [1]. Considered this anatomical challenging point, traveling to high-volume centers for the treatment of RPS confers a significant short-term and long-term survival advantage [8].

Although several studies have assessed the survival benefits of wide excision, few have reported detailed methods for achieving wide excision in patients with RPS. Therefore, the present study aimed to describe our experiences with multidisciplinary surgical resection in patients with RPS, including both intra- and extrapelvic approaches. Our multidisciplinary surgical approach used an anatomical approach to tumor removal combining intra- and extraperitoneal RPS access, respectively (Fig. 1). Even though this two-step approaches were more invasive than conventional approach, this is a potential solution for overcoming the surgical limitations of anatomic location in the retroperitoneal space.

\section{Method}

Eligible patients seen at Seoul St. Mary's Hospital, the College of Medicine at The Catholic University of Korea were identified based on their surgical history of RPS. Only patients who underwent surgical treatment with both intra- and extrapelvic approaches were included in the current study, regardless of their disease state. We evaluated medical records between Jan 2001 and Feb 2020, including patient age, body mass index (BMI), mass size, whether neoadjuvant or adjuvant treatments were used, final histology following surgical resection, and surgical outcomes (i.e., approach method, estimated blood loss, transfusion during operation, overall survival [OS], and progression-free survival [PFS] with each treatment). The retroperitoneal mass size was reported based on its long axis. This study was approved by the Institutional Review Board of Seoul St. Mary's Hospital (approved number: KC20RISI0350).

\section{Result}

Ten Intra and Extra pelvic surgical treatment were given to 8 patients from Sep 2014. The patients' mean age and BMI were 42.75 years (range, 14-78 years) and 22.4 (range, 17.6-24), respectively. The median mass size was $12.75 \mathrm{~cm}$ (range, 6-45.5 cm). The masses extended from intra- to retroperitoneal areas. Palpable mass or pain at specific sites were each reported as the initial symptom in 4 patients. Three patients underwent multidisciplinary surgery as the primary surgical resection, while the others underwent a secondary or greater surgical resection 
(Table 1). Before doing surgery, all cases were discussed about resectability, necessary pre-operative procedure, predicted complications in multidisciplinary cooperative center, department of oncology, Seoul St. Mary's hospital. In routine system, contact to specialized doctor is available in every surgical time due to hospital policy. We could ask another surgical team to join our surgery in any time when we were doing operation.

Table 1

Characteristics of patients with retroperitoneal sarcoma $(n=8)$

\begin{tabular}{|c|c|}
\hline \multicolumn{2}{|l|}{ Characteristics } \\
\hline Mean age (years) & $42.75 \pm 18.4$ \\
\hline Mean BMI & $22.4 \pm 2.4$ \\
\hline \multicolumn{2}{|l|}{ Initial symptoms } \\
\hline 1) Palpable mass & $4(50 \%)$ \\
\hline 2) Pain on specific site & $4(50 \%)$ \\
\hline Median Mass size (long axis, $\mathrm{cm}$ ) & $12.75 \pm 11.7$ \\
\hline \multicolumn{2}{|l|}{ Order of surgery } \\
\hline 1) primary & $3(30 \%)$ \\
\hline 2) secondary & $2(25 \%)$ \\
\hline 3) tertiary & $2(25 \%)$ \\
\hline 4) more than tertiary & $3(30 \%)$ \\
\hline \multicolumn{2}{|l|}{ History of Neoadjuvant or adjuvant treatment } \\
\hline 1) Neoadjuvant Treatment & $2(25 \%)$ \\
\hline 2) Adjuvant Treatment & $8(100 \%)$ \\
\hline \multicolumn{2}{|l|}{ Surgical outcome } \\
\hline 1) Median overall survival (month, median) & 64.6 \\
\hline 2) Progression free survival (month, median) & 13.7 \\
\hline 3) Died patients due to disease & $2(25 \%)$ \\
\hline \multicolumn{2}{|l|}{ Pathology } \\
\hline 1) Liposarcoma & $2(25 \%)$ \\
\hline 2) Leiomyosarcoma & $1(12.5 \%)$ \\
\hline 3) Malignant peripheral nerve sheath tumor & $1(12.5 \%)$ \\
\hline 4) Osteosarcoma & $1(12.5 \%)$ \\
\hline 5) Chondrosarcoma & $1(12.5 \%)$ \\
\hline 6) Low-grade fibromyxoid sarcoma & $1(12.5 \%)$ \\
\hline
\end{tabular}

For the intrapelvic approach, laparoscopy-assisted surgery was performed on 4 patients, and laparotomy surgery with midline incision was performed on 6 patients. For the extrapelvic approach, ilioinguinal and posterior approaches were each used in 4 patients, while prone position and midline skin incision were shared in 1 patient. In all 10 procedures, wide or marginal mass excision was performed with resection of suspicious tumor invasion structures. Also pelvic organ (sigmoid colon, external or internal iliac vessel) were dissected and mobilized by several special doctors. Additionally, pelvic lymph node dissections or prophylactic fixation or revision of structures were conducted. In all 10 cases, median 3 surgical teams (range, 2-5 teams) were co-operated to remove RPS. Colorectal or vascular team of general surgery, gynecologic oncology team, bone tumor or spine part of orthopedic surgery, and urology doctors were took part in multidisciplinary surgery. (Table 2 ). 
Table 2

Surgical approach and outcomes (total 10 cases)

\begin{tabular}{|c|c|c|c|c|c|c|c|c|c|c|c|}
\hline \multirow[t]{2}{*}{ PN } & \multirow{2}{*}{$\begin{array}{l}\text { Number of } \\
\text { surgery }\end{array}$} & \multirow{2}{*}{$\begin{array}{l}\text { Intra pelvic } \\
\text { surgery } \\
\text { Approach } \\
\text { method \& } \\
\text { operation } \\
\text { title }\end{array}$} & \multirow{2}{*}{$\begin{array}{l}\text { Extra pelvic } \\
\text { surgery } \\
\text { Approach } \\
\text { method \& } \\
\text { Operation } \\
\text { title }\end{array}$} & \multirow[t]{2}{*}{ Pathology } & \multicolumn{2}{|c|}{ Resection margin } & \multirow{2}{*}{$\begin{array}{l}\text { EBL } \\
\text { [ml] }\end{array}$} & \multirow{2}{*}{$\begin{array}{l}\text { Transfusion } \\
\text { during } \\
\text { operation }\end{array}$} & \multirow[t]{2}{*}{$H D$} & \multirow{2}{*}{$\begin{array}{l}\text { os } \\
\text { [mo.] }\end{array}$} & \multirow{2}{*}{$\begin{array}{l}\text { PFS } \\
\text { [mo.] }\end{array}$} \\
\hline & & & & & $\begin{array}{l}\text { Intra } \\
\text { pelvic } \\
\text { surgery }\end{array}$ & $\begin{array}{l}\text { Extra } \\
\text { pelvic } \\
\text { surgery }\end{array}$ & & & & & \\
\hline 1 & $\begin{array}{l}\text { Primary } \\
\text { surgery }\end{array}$ & $\begin{array}{l}\text { - } \\
\text { Laparoscopy } \\
\text {-Mass } \\
\text { excision }\end{array}$ & $\begin{array}{l}\text {-Posterior } \\
\text { approach of } \\
\text { hip } \\
\text {-Wide } \\
\text { excision }\end{array}$ & WDLPS & RO & Ro & 300 & No & 15 & 65.3 & 13.7 \\
\hline 1 & $\begin{array}{l}\text { Secondary } \\
\text { surgery }\end{array}$ & $\begin{array}{l}\text {-Laparotomy } \\
\text {-Mass } \\
\text { excision } \\
\text {-Dissection } \\
\text { and } \\
\text { mobilization } \\
\text { of Lt. } \\
\text { internal iliac } \\
\text { vessel } \\
\text {-Ligation of } \\
\text { Lt. iliac vein }\end{array}$ & $\begin{array}{l}\text { Laparotomy } \\
\text {-Marginal } \\
\text { excision } \\
\text { Neurolysis }\end{array}$ & WDLPS & $\mathrm{R} 1$ & $\mathrm{R} 1$ & 2000 & Yes & 17 & 65.3 & 50 \\
\hline 2 & $\begin{array}{l}\text { 5th } \\
\text { surgery }\end{array}$ & $\begin{array}{l}\text {-Laparotomy } \\
\text {-Mass } \\
\text { excision }\end{array}$ & $\begin{array}{l}\text {-llioinguinal } \\
\text { approach } \\
\text {-Wide } \\
\text { excision }\end{array}$ & LMS & $\mathrm{R} 1$ & Ro & 1250 & Yes & 19 & 97 & 9 \\
\hline 3 & $\begin{array}{l}\text { Secondary } \\
\text { surgery }\end{array}$ & $\begin{array}{l}\text { - } \\
\text {-Rt. RSO and } \\
\text { PLND } \\
\text {-Sigmoid } \\
\text { colon } \\
\text { mobilization } \\
\text {-Dissection } \\
\text { of Rt. } \\
\text { external and } \\
\text { internal iliac } \\
\text { vessel }\end{array}$ & $\begin{array}{l}\text {-llioinguinal } \\
\text { approach } \\
\text {-Wide } \\
\text { excision }\end{array}$ & MPNST & Ro & $\mathrm{R} 1$ & 10000 & Yes & 42 & 63.9 & 4.3 \\
\hline 4 & $\begin{array}{l}\text { Primary } \\
\text { surgery }\end{array}$ & $\begin{array}{l}\text {-Laparotomy } \\
\text {-Mass } \\
\text { excision } \\
\text {-Dissection } \\
\text { of Lt. } \\
\text { common } \\
\text { and external } \\
\text { iliac vessel } \\
\text {-Ligation of } \\
\text { Lt. internal } \\
\text { iliac artery }\end{array}$ & $\begin{array}{l}\text {-Posterior } \\
\text { approach of } \\
\text { hip } \\
\text {-Wide } \\
\text { excision } \\
\text { Neurolysis }\end{array}$ & $\begin{array}{l}\text { Myxoid } \\
\text { liposarcoma }\end{array}$ & Ro & $\mathrm{R} 1$ & 2000 & Yes & 16 & 55.7 & 49 \\
\hline
\end{tabular}

PN, patient number; EBL, estimated blood loss; HD, hospitalization days; OS, overall survival; PFS, progression free survival; WDLPS, well differentiated liposarcoma; LMS, leiomyosarcoma; MPNST, Malignant peripheral nerve sheath tumor; LGFMS, Low-grade fibromyxoid sarcoma; RSO, Rt. salpingo-oophorectomy; PLND,pelvic lymphnode dissection 


\begin{tabular}{|c|c|c|c|c|c|c|c|c|c|c|c|}
\hline \multirow[t]{2}{*}{ PN } & \multirow{2}{*}{$\begin{array}{l}\text { Number of } \\
\text { surgery }\end{array}$} & \multirow{2}{*}{$\begin{array}{l}\text { Intra pelvic } \\
\text { surgery } \\
\text { Approach } \\
\text { method \& } \\
\text { operation } \\
\text { title }\end{array}$} & \multirow{2}{*}{$\begin{array}{l}\text { Extra pelvic } \\
\text { surgery } \\
\text { Approach } \\
\text { method \& } \\
\text { Operation } \\
\text { title }\end{array}$} & \multirow[t]{2}{*}{ Pathology } & \multicolumn{2}{|c|}{ Resection margin } & \multirow{2}{*}{$\begin{array}{l}\text { EBL } \\
{[\mathrm{ml}]}\end{array}$} & \multirow{2}{*}{$\begin{array}{l}\text { Transfusion } \\
\text { during } \\
\text { operation }\end{array}$} & \multirow[t]{2}{*}{ HD } & \multirow{2}{*}{$\begin{array}{l}\text { OS } \\
\text { [mo.] }\end{array}$} & \multirow{2}{*}{$\begin{array}{l}\text { PFS } \\
\text { [mo. }\end{array}$} \\
\hline & & & & & $\begin{array}{l}\text { Intra } \\
\text { pelvic } \\
\text { surgery }\end{array}$ & $\begin{array}{l}\text { Extra } \\
\text { pelvic } \\
\text { surgery }\end{array}$ & & & & & \\
\hline \multirow[t]{4}{*}{5} & \multirow{4}{*}{$\begin{array}{l}\text { Tertiary } \\
\text { surgery }\end{array}$} & -Laparotomy & -Posterior & \multirow[t]{4}{*}{ Osteosarcoma } & \multirow[t]{4}{*}{ Ro } & \multirow[t]{4}{*}{ Ro } & \multirow[t]{4}{*}{20000} & \multirow[t]{4}{*}{ Yes } & \multirow[t]{4}{*}{52} & \multirow[t]{4}{*}{52} & \multirow[t]{4}{*}{11.5} \\
\hline & & \multirow{3}{*}{$\begin{array}{l}\text {-Mass } \\
\text { excision, } \\
\text {-Rectum } \\
\text { mobilization }\end{array}$} & hip & & & & & & & & \\
\hline & & & $\begin{array}{l}\text {-Wide } \\
\text { excision, }\end{array}$ & & & & & & & & \\
\hline & & & $\begin{array}{l}\text { Neurotomy } \\
\text { L5-S1 }\end{array}$ & & & & & & & & \\
\hline \multirow[t]{4}{*}{6} & \multirow{4}{*}{$\begin{array}{l}\text { Tertiary } \\
\text { surgery }\end{array}$} & -Laparotomy & -llioinguinal & \multirow[t]{4}{*}{ LGFMS } & \multirow[t]{4}{*}{ R1 } & \multirow[t]{4}{*}{ Ro } & \multirow[t]{4}{*}{12000} & \multirow[t]{4}{*}{ Yes } & \multirow[t]{4}{*}{67} & \multirow[t]{4}{*}{206.8} & \multirow[t]{4}{*}{28.9} \\
\hline & & \multirow{2}{*}{$\begin{array}{l}\text {-Mass } \\
\text { excision } \\
\text { - Int. iliac - } \\
\text { deep } \\
\text { femoral } \\
\text { artery, } \\
\text { allograft } \\
\text { bypass }\end{array}$} & $\begin{array}{l}\text {-Marginal } \\
\text { excision }\end{array}$ & & & & & & & & \\
\hline & & & $\begin{array}{l}\text { skin flap } \\
\text { and graft }\end{array}$ & & & & & & & & \\
\hline & & $\begin{array}{l}\text { - Rt. D-J } \\
\text { catheter } \\
\text { insertion } \\
\text { with primary } \\
\text { bladdder } \\
\text { repair }\end{array}$ & & & & & & & & & \\
\hline \multirow[t]{2}{*}{6} & $\begin{array}{l}\text { Quaterary } \\
\text { surgery }\end{array}$ & -Laparotomy & $\begin{array}{l}\text {-Prone } \\
\text { position }\end{array}$ & Osteosarcoma & $\mathrm{R} 1$ & Ro & 700 & Yes & 12 & 206.8 & 14.6 \\
\hline & & $\begin{array}{l}\text {-Mass } \\
\text { excision }\end{array}$ & $\begin{array}{l}\text {-Wide } \\
\text { excision }\end{array}$ & & & & & & & & \\
\hline 7 & $\begin{array}{l}\text { Primary } \\
\text { surgery }\end{array}$ & Laparoscopy & $\begin{array}{l}\text {-Posterior } \\
\text { approach of } \\
\text { hip }\end{array}$ & $\begin{array}{l}\text { Malignant } \\
\text { spindle cell } \\
\text { tumor }\end{array}$ & Ro & Ro & 10000 & Yes & 69 & 11.4 & 7.5 \\
\hline & & $\begin{array}{l}\text {-Mass } \\
\text { excision }\end{array}$ & $\begin{array}{l}\text {-Wide } \\
\text { excision }\end{array}$ & & & & & & & & \\
\hline & & $\begin{array}{l}\text {-Dissection } \\
\text { and } \\
\text { mobilization } \\
\text { of } L t \text {. } \\
\text { external and } \\
\text { internal iliac } \\
\text { vessel }\end{array}$ & $\begin{array}{l}\text { Neurolysis } \\
\text { L5 S3, Lt. }\end{array}$ & & & & & & & & \\
\hline 8 & $\begin{array}{l}\text { 5th } \\
\text { surgery }\end{array}$ & Laparoscopy & $\begin{array}{l}\text {-llioinguinal } \\
\text { approach }\end{array}$ & Chondrosarcoma & Ro & Ro & 300 & Yes & 9 & 115 & 13.7 \\
\hline & & $\begin{array}{l}\text {-Mass } \\
\text { excision, Rt. } \\
\text { PLND }\end{array}$ & $\begin{array}{l}\text {-Marginal } \\
\text { excision }\end{array}$ & & & & & & & & \\
\hline & & $\begin{array}{l}\text {-Primary } \\
\text { closure of } \\
\text { Rt. external } \\
\text { iliac vein }\end{array}$ & & & & & & & & & \\
\hline
\end{tabular}

Prior to surgery, 6 patients underwent arterial embolization to reduce blood loss; nevertheless, their estimated median blood loss was $2000 \mathrm{~mL}$ (range, 300-20 000 mL) and 9 patients received transfused blood intraoperatively. Ligation of internal iliac vessel for 1 patient, dissection with mobilization of iliac vessel for 3 patients were conducted by vascular surgical team. Also, internal iliac artery-deep femoral artery allograft bypass was done by vascular surgical team in 1 patient. Another one dissection and primary closure of iliac vessel were done by gynecologic oncology team. These procedures was necessary to achieve surgical margin and reduce blood loss. 
The median hospitalization duration was 12.6 days (range, 9-69 days). Reoperation was needed in 2 patients, one for wound necrosis and the other for bowel perforation and wound necrosis. There were no postoperative deaths.

All of the patients removed total tumor mass by macroscopically and 4 patients (40\%) were achieved R0 resection through intra and extra pelvic surgical treatment. The most common histology of RPS (2 patients) was myxoid type of well-differentiated liposarcoma. One each leiomyosarcoma (LMS), malignant peripheral nerve sheath tumor (MPNST), osteosarcoma, chondrosarcoma, low-grade fibromyxoid sarcoma (LGFMS), malignant spindle cell tumor were also noted. Neoadjuvant chemotherapy was performed in 2 patients and all patients received adjuvant treatments (RT and/or chemotherapy).

Five patients are currently living. Two died due to RPS progression and 1 was lost to follow-up. Among the 5 living patients, disease progression was reported in 3, while 2 showed no progression. The median OS was 64.6 months (range, 11.4-206.8 months) and the median PFS following treatment was 13.7 months (range, 4.3-50.6 months).

\section{Discussion}

RPSs consist a heterogeneous group of malignant tumors with very low incidence; and very little is known about their biological behavior and no specific causative compounds have been identified [9]. Macroscopically clear margin is one of the important prognostic factors in RPS's patients [9]. However, securing a clear margin is quite challenging due to the tumor location. Malinka et.al, macroscopically clear margin was reported in $84 \%$ (51, total 61 ) [10]. The other study, Hogg et. al, it was notified in $88.9 \%$ (80, total 90$)$ [11]. Our finding that all patients had a macroscopically clear margin is thus superior to conventional studies.

RPS patients were used all treatment method currently available, including surgical approaches, chemotherapy or target therapy, and Radiotherapy (RT). RT were treatment options we used to deal with patients. RT is usually used to control local recurrence or improve the surgical margin; however, it does not impact on distant metastasis or overall survival (OS) [12]. Haas et al. reported that preoperative RT was associated with better local control in unadjusted univariate analysis among their three cohorts, but not after accounting for imbalances in prognostic variables [12]. According to Turner et al., however, compared with resection alone, additional neoadjuvant RT was associated with multivisceral resection ( $87.5 \%$ vs. $66.1 \%, p=0.02)$ and negative margins $(72.5 \%$ vs. $30.6 \%, p<0.001)$ [13]. Roeder at al. also reported that combination of neoadjuvant Intensity-Modulated RT, surgery and intraoperative RT is feasible with acceptable toxicity and yields good results in terms of local control and overall survival in patients with high-risk retroperitoneal sarcomas (Estimated 3- and 5-year local control rates of 72\%, estimated 3and 5-year overall survival rates of 74\%) [14]. This method showed superior effectiveness at achieving a surgical margin compared to neoadjuvant RT alone (R0 in 6 patients [22\%] and R1 in 22 patients [74\%]). The combination method showed a rate with a macroscopically clear margin like ours (100\%), but including several side effects and limitations. First, the combination method had more reported postoperative side effects. Nine patients (30\%) had more than grade 3 postoperative side effects, 4 patients (15\%) needed reoperations, and 2 patients died during the prolonged postoperative period. These rates are higher than ours: e.g., 2 patients (20\%) underwent reoperation and none died postoperatively. Another limitation of the combination method is that it should only be administered to inpatients in a hospital with appropriate facilities for intensity-modulated and intraoperative RT. Thus, toward gaining a clear margin, a multidisciplinary surgical approach is a good option for treating patients with RPS.

The efficacy of chemotherapy or immunotherapy for RPS is limited. The role of adjuvant/neo-adjuvant systemic therapy is not well defined due to the rarity of the disease and paucity of randomized controlled data. The role of palliative systemic therapy is better established, however mostly through extrapolation of data from results on sarcomas of other locations [15]. Currently, anthracycline-based therapy remains standard first-line treatment [16]. But it induces response in just 15-35\% of patients, irrespective of the histological subtype [17]. Thus, complete surgical resection is considered a RPS treatment milestone. Several agents have recently emerged as second-line treatment options, including gemcitabine/docetaxel, high-dose ifosfamide monotherapy, trabectedin, pazopanib, and eribulin. According to PALETTE study, pazopanib significantly increased progression-free survival compared with placebo in metastatic soft-tissue sarcoma, progressing despite previous standard chemotherapy [18]. According to Dickson at. al, the selective CDK4 and CDK6 inhibitor palbociclib inhibits growth and induces senescence in liposarcoma cell lines and there was favor of progression free survival nevertheless, there was no significant difference in progression free survival between patients who had or had not received prior systemic therapy $(P=.70)$ [19]. Depending on histology type, there are several randomized controlled trial about neo-adjuvant or systemic chemotherapy. The EORTC-1809-STBSG- STRASS 2 study, intended to be an international randomized multicenter, open-label phase 3 trial, with stratification by specific tumor histology and including only high-grade dedifferentiated liposarcoma and LMS [20]. The study aim is to evaluate whether neoadjuvant chemotherapy reduces the development of distant metastasis in these well-defined histologic entities [20]. Thus, we're waiting for this result to know the efficacy of neoadjuvant chemotherapy.

Without doubt, complete surgical resection and securing a clear surgical margin is the most effective therapeutic method. However, as described above, surgical treatment is challenging for most surgeons because of the RPS location. To overcome this obstacle, neoadjuvant and/or adjuvant therapy was developed and the Trans-Atlantic RPS Working Group was established in 2013. This group insisted on the importance of a

Page 6/10 
presurgical imaging study and multidisciplinary discussion for patients with RPS. They also noted that complete resection should be accomplished despite large adjacent organ resection [1]. Thus, an interdisciplinary collaboration among teams of surgeons, anesthesiologists, and nurses is necessary to achieve complete RPS resection.

Several side effects were noted following a multidisciplinary approach to RPS resection. Though there were no deaths among our sample, reoperation was needed in 2 patients. One patient underwent wound revision and local flap coverage for wound necrosis 17 days postoperative. The other patient's complications were more severe (i.e., bowel perforation, wound necrosis), requiring exploratory laparotomy with ileostomy and wound debridement with flap coverage almost one month postoperatively. Compared to pelvic exenteration for recurrent or advanced cervical cancer, one of the challenging surgeries in gynecological cancer, our multidisciplinary two-step approach made higher wound complication than pelvic exenteration. (20\% vs. 4.3\%) [21]. Long hospitalizations (range, 9-69 days) and large estimated blood loss volumes (range, $300-20000 \mathrm{~mL}$ ) were also found, despite $60 \%$ of patients receiving preoperative arterial embolization. Patients in all 10 cases also required transfused packed red blood cells, fresh frozen plasma, and/or platelets. Despite these severe complications, the multidisciplinary approach achieved a clear margin rate of $100 \%$. Thus, it is a superior method compared to the conventional single-incision approach. According to Bizzarri, N. et al, minimal invasive surgery could be applied challenging surgery keeping same survival outcomes compared to conventional surgery [22]. This two-step approach also has chance to be changed minimal invasive surgery using robotic system or other advanced surgical method. That could be decreased complication rates in RPS patients applied two-step approach. Further, this complication rate is lower than that found in combination RT and surgery, which achieved a similar clear surgical margin rate. In addition, using pre-operative vascular assessment (Tinelli's Score) could be new options to achieve surgical margin and reduce blood loss [20, 23]. We had been discussed several factors influenced surgical status before surgery, and we did arterial embolization if cancerous mass located or invaded in major vessel. But we didn't use of this evaluation system at pre-operation. So, we checked up our data retrospectively by using Tinelli's Score. Among 10 cases, 6 cases $(60 \%)$ were included in Grade 1 or 2 and 2 cases were in grade 3. One case was each in grade 4 and 5 and major vessel allograft was done in case noted grade 5 vessel invasion. Among 4 cases at upper grade 3, arterial embolization was conducted in 3 cases. So, checking of invasion grade in vessel, doing arterial embolization before surgery, and co-operation with vascular surgical team could make not only achieve for complete resection of tumor but also reduce blood loss and surgical complications in next surgery. Finally, applying enhanced recovery after surgery (ERAS) or a modified ERAS method, may reduce both hospitalizations and postoperative complications.

These findings support the need for a multicenter or randomized control study to test the effectiveness of the multidisciplinary approach, despite the Trans-Atlantic RPS Working Group's current guideline that the multidisciplinary approach is superior for complete tumor resection.

\section{Conclusion}

Therapeutic challenges from RPS are based on their location and high risk of recurrence. As such, a multidisciplinary approach is necessary to improve patient outcomes. The location of RPS and benefits of using both an intra- and extrapelvic treatments makes this a good candidate for the multidisciplinary approach. This approach may improve securing a macroscopic surgical margin.

\section{Abbreviations}

RPS

retroperitoneal sarcoma, WDLPS:well differentiated liposarcoma, DDLPS:dedifferentiated liposarcoma, LMS:leiomyosarcoma, SFT:solitary fibrous tumor, MPNST:malignant peripheral nerve sheath tumor, UPS:synovial sarcoma and undifferentiated pleomorphic sarcoma, $\mathrm{RT}$ :radiotherapy, BMl:body mass index, OS:overall survival, PFS:progression-free survival, LGFMS:Iow-grade fibromyxoid sarcoma

\section{Declarations}

\section{Acknowledgements}

Not applicable

\section{Authors' Contributions}

$\mathrm{KHL}, \mathrm{YKJ}$, and HS designed the study. HS, JHA, YJ, and JYW analyzed the data and HS wrote the draft of the manuscript. All other authors have contributed to data collection and interpretation, and critically reviewed the manuscript. KHL and YKJ supervised the study. All authors read and approved the final manuscript.

\section{Funding}

The authors received no funding for this study. 
Availability of data and materials

The datasets used and/or analyzed during the current study are available from the corresponding author on reasonable request.

\section{Ethics approval and consent to participate}

This retrospective study was approved by the Institutional Review Board of Seoul St. Mary's Hospital (approved number: KC20RISI0350).

\section{Consent for publication}

Not applicable

\section{Competing interests}

The authors declare that they have no competing interests.

\section{Author details}

${ }^{7}$ Department of Obstetrics and Gynecology, Seoul St. Mary's Hospital, College of Medicine, The Catholic University of Korea, Seoul, Republic of Korea

${ }^{2}$ Department of Orthopedic Surgery, Seoul St. Mary's Hospital, College of Medicine, The Catholic University of Korea, Seoul, Republic of Korea

\section{References}

1. Management of primary retroperitoneal. sarcoma (RPS) in the adult: a consensus approach from the Trans-Atlantic RPS Working Group. Ann Surg Oncol. 2015;22(1):256-63.

2. Tan MC, Brennan MF, Kuk D, Agaram NP, Antonescu CR, Qin LX, Moraco N, Crago AM, Singer S. Histology-based Classification Predicts Pattern of Recurrence and Improves Risk Stratification in Primary Retroperitoneal Sarcoma. Ann Surg. 2016;263(3):593-600.

3. Gronchi A, Strauss DC, Miceli R, Bonvalot S, Swallow CJ, Hohenberger P, Van Coevorden F, Rutkowski P, Callegaro D, Hayes AJ, et al. Variability in Patterns of Recurrence After Resection of Primary Retroperitoneal Sarcoma (RPS): A Report on 1007 Patients From the Multiinstitutional Collaborative RPS Working Group. Ann Surg. 2016;263(5):1002-9.

4. Management of Recurrent Retroperitoneal. Sarcoma (RPS) in the Adult: A Consensus Approach from the Trans-Atlantic RPS Working Group. Ann Surg Oncol. 2016;23(11):3531-40.

5. van Houdt WJ, Zaidi S, Messiou C, Thway K, Strauss DC, Jones RL. Treatment of retroperitoneal sarcoma: current standards and new developments. Curr Opin Oncol. 2017;29(4):260-7.

6. Paik ES, Kang JH, Kim J, Lee Y-J, Choi CH, Kim T-J, Kim B-G, Bae D-S, Lee J-W. Prognostic factors for recurrence and survival in uterine leiomyosarcoma: Korean single center experience with 50 cases. Obstet Gynecol Sci. 2019;62(2):103-11.

7. Cananzi FCM, Ruspi L, Sicoli F, Minerva EM, Quagliuolo V. Did outcomes improve in retroperitoneal sarcoma surgery? Surg Oncol. 2019;28:96-102.

8. Schmitz R, Adam MA, Blazer DG. 3rd: Overcoming a travel burden to high-volume centers for treatment of retroperitoneal sarcomas is associated with improved survival. World J Surg Oncol. 2019;17(1):180.

9. Mantas D, Garmpis N, Polychroni D, Garmpi A, Damaskos C, Liakea A, Sypsa G, Kouskos E. Retroperitoneal sarcomas: from diagnosis to treatment. Case series and review of the literature. G Chir. 2020;41(1):18-33.

10. Malinka T, Nebrig M, Klein F, Pratschke J, Bahra M, Andreou A. Analysis of outcomes and predictors of long-term survival following resection for retroperitoneal sarcoma. BMC Surg. 2019;19(1):61.

11. Hogg HD, Manas DM, Lee D, Dildey P, Scott J, Lunec J, French JJ. Surgical outcome and patterns of recurrence for retroperitoneal sarcoma at a single centre. Ann R Coll Surg Engl. 2016;98(3):192-7.

12. Haas RLM, Bonvalot S, Miceli R, Strauss DC, Swallow CJ, Hohenberger P, van Coevorden F, Rutkowski P, Callegaro D, Hayes AJ, et al. Radiotherapy for retroperitoneal liposarcoma: A report from the Transatlantic Retroperitoneal Sarcoma Working Group. Cancer. 2019;125(8):1290-300.

13. Turner BT, Hampton L, Schiller D, Mack LA, Robertson-More C, Li H, Quan ML, Bouchard-Fortier A. Neoadjuvant radiotherapy followed by surgery compared with surgery alone in the treatment of retroperitoneal sarcoma: a population-based comparison. Curr Oncol. 2019;26(6):e766-72.

14. Roeder F, Ulrich A, Habl G, Uhl M, Saleh-Ebrahimi L, Huber PE, Schulz-Ertner D, Nikoghosyan AV, Alldinger I, Krempien R, et al. Clinical phase $\mathrm{I} / \mathrm{II}$ trial to investigate preoperative dose-escalated intensity-modulated radiation therapy (IMRT) and intraoperative radiation therapy (IORT) 
in patients with retroperitoneal soft tissue sarcoma: interim analysis. BMC Cancer. 2014;14:617.

15. Constantinidou A, Jones RL. Systemic therapy in retroperitoneal sarcoma management. J Surg Oncol. 2018;117(1):87-92.

16. van Houdt WJ, Raut CP, Bonvalot S, Swallow CJ, Haas R, Gronchi A. New research strategies in retroperitoneal sarcoma. The case of TARPSWG, STRASS and RESAR: making progress through collaboration. Curr Opin Oncol. 2019;31(4):310-6.

17. Almond LM, Gronchi A, Strauss D, Jafri M, Ford S, Desai A. Neoadjuvant and adjuvant strategies in retroperitoneal sarcoma. Eur J Surg Oncol. 2018;44(5):571-9.

18. van der Graaf WT, Blay JY, Chawla SP, Kim DW, Bui-Nguyen B, Casali PG, Schöffski P, Aglietta M, Staddon AP, Beppu Y, et al. Pazopanib for metastatic soft-tissue sarcoma (PALETTE): a randomised, double-blind, placebo-controlled phase 3 trial. Lancet. 2012;379(9829):1879-86.

19. Dickson MA, Schwartz GK, Keohan ML, D'Angelo SP, Gounder MM, Chi P, Antonescu CR, Landa J, Qin LX, Crago AM, et al. Progression-Free Survival Among Patients With Well-Differentiated or Dedifferentiated Liposarcoma Treated With CDK4 Inhibitor Palbociclib: A Phase 2 Clinical Trial. JAMA Oncol. 2016;2(7):937-40.

20. Management of metastatic. retroperitoneal sarcoma: a consensus approach from the Trans-Atlantic Retroperitoneal Sarcoma Working Group (TARPSWG). Ann Oncol. 2018;29(4):857-71.

21. Ter Glane L, Hegele A, Wagner U, Boekhoff J. Pelvic exenteration for recurrent or advanced gynecologic malignancies - Analysis of outcome and complications. Gynecol Oncol Rep. 2021;36:100757.

22. Bizzarri N, Chiantera V, Ercoli A, Fagotti A, Tortorella L, Conte C, Cappuccio S, Di Donna MC, Gallotta V, Scambia G, et al. Minimally Invasive Pelvic Exenteration for Gynecologic Malignancies: A Multi-Institutional Case Series and Review of the Literature. J Minim Invasive Gynecol. 2019;26(7):1316-26.

23. Vizzielli G, Chiantera V, Tinelli G, Fagotti A, Gallotta V, Di Giorgio A, Gueli Alletti S, Scambia G. Out-of-the-box pelvic surgery including iliopsoas resection for recurrent gynecological malignancies: Does that make sense? A single-institution case-series. Eur J Surg Oncol. 2017;43(4):710-6.

\section{Figures}

(a)

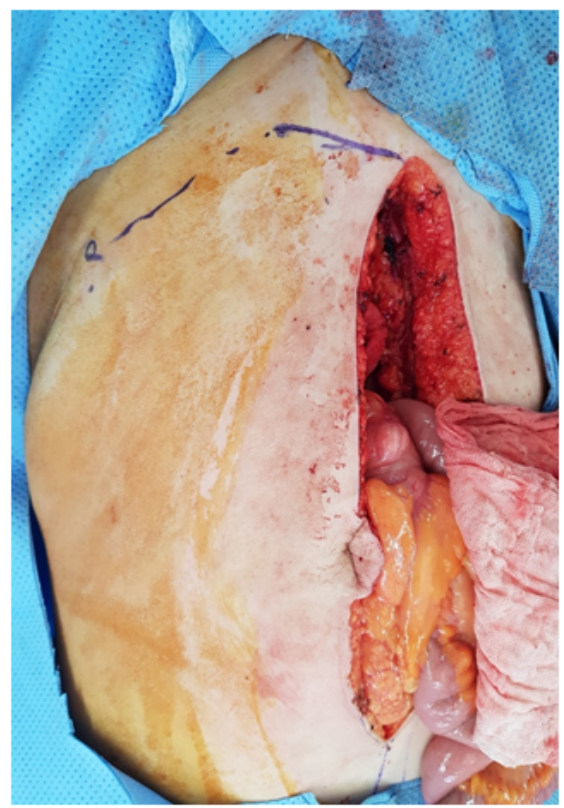

(b)

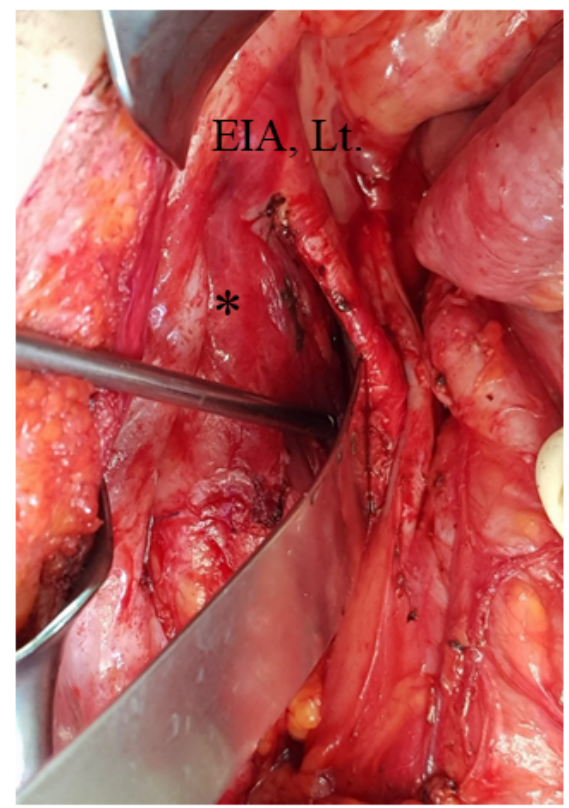

(c)

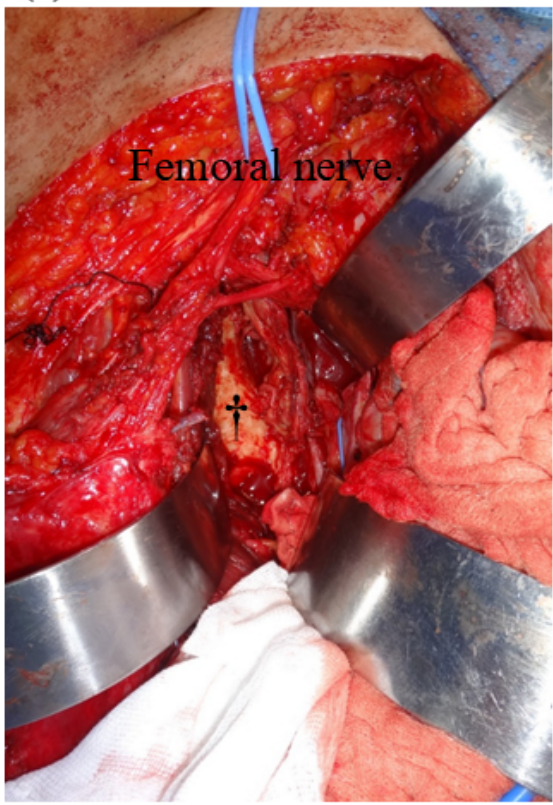

Figure 1

Operative fields of multidisciplinary approach (a) Incision of intra and extra pelvic approach (mid line incision + ilioinguinal approach) (b) Intra pelvic approach surgical field (c) Extra pelvic approach surgical field *: medical part of sarcoma mass, soft tissue of obturator internus, †: lateral part of sarcoma mass, from ilium and ischium, EIA: external iliac artery 
(a)

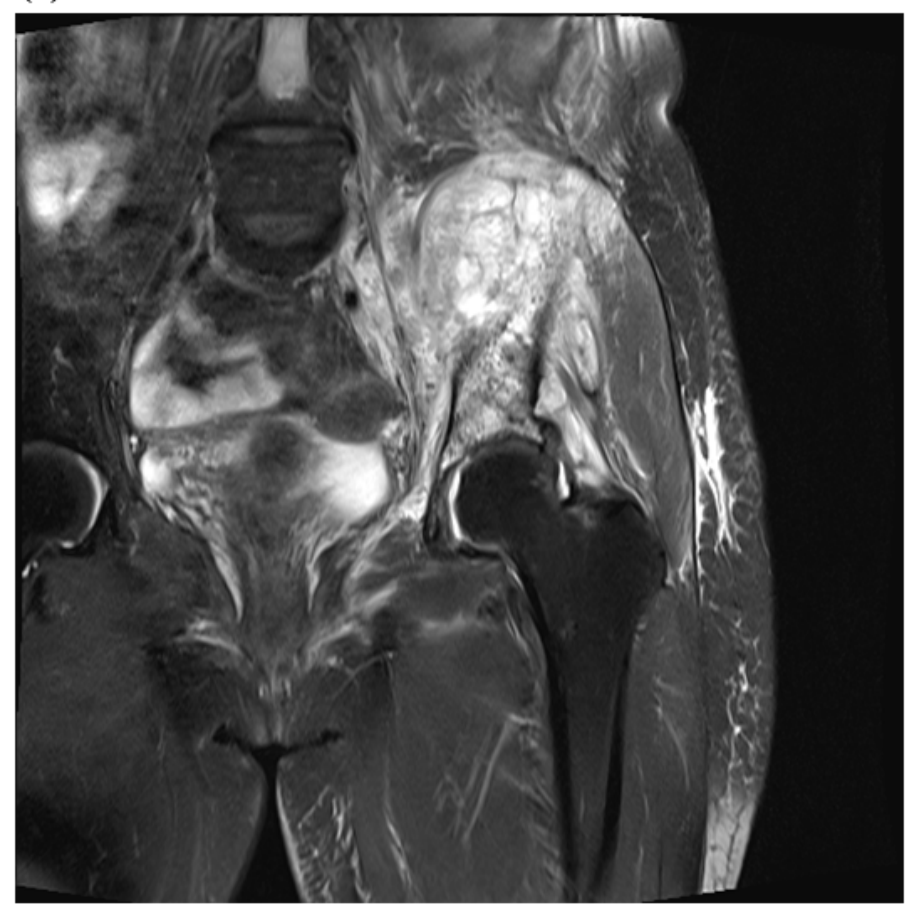

(b)

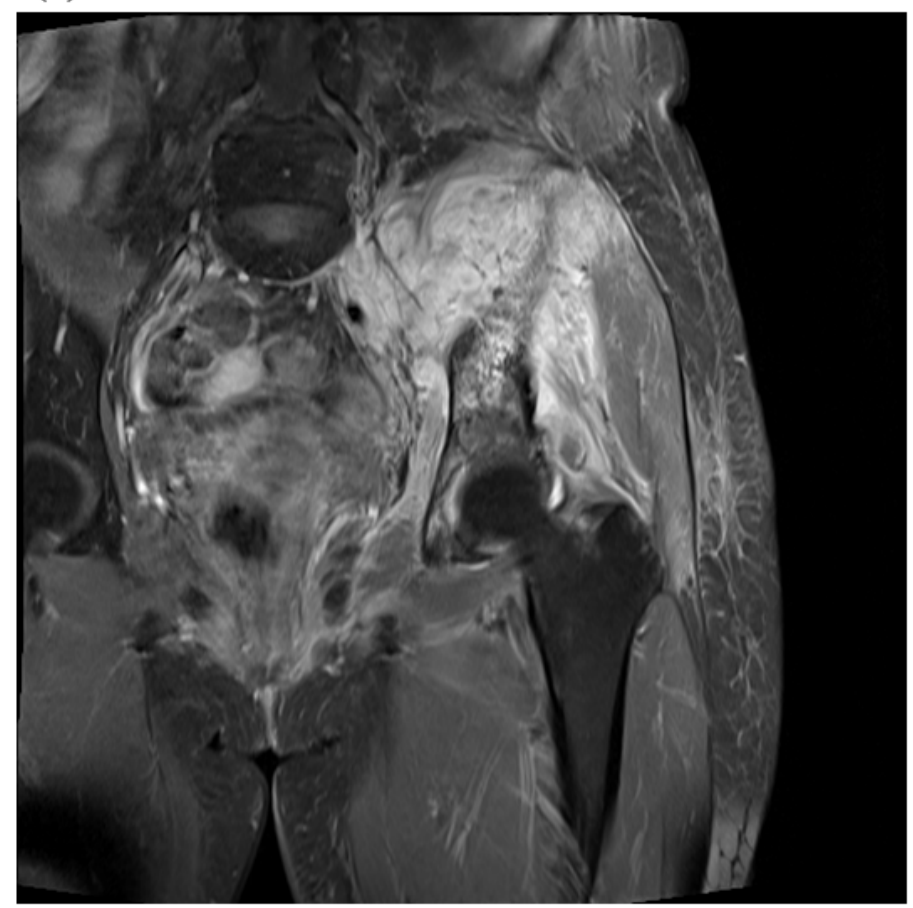

Figure 2

Magnetic resonance image of retroperitoneal sarcoma involved Lt. pelvis (iliac bone, obturator internus muscles, and, common and internal iliac lymph nodes) (a) Coronal T2 weighted image (b) Coronal T1 weighted fat suppression image (c) Extra pelvic approach surgical field (wide excision) 